\title{
Refinement of paleomagnetic data for Meso-Neoproterozoic rocks of the southeast of the Siberian platform
}

\author{
ALEKSANDR D. SAVELEV ${ }^{1}$, ALEKSANDR M. PASENKO ${ }^{2}$ \\ AND ANNA A. PAZUKHINA ${ }^{1}$ \\ ${ }^{1}$ St. Petersburg State University \\ ${ }^{2}$ Schmidt Institute of Physics of the Earth RAS \\ Presenting Author: aleksandr.d.savelev@gmail.com
}

The problem of the Precambrian segment of the apparent polar wander path (APWP) for Siberia is still under discussion. The 950 Ma-paleomagnetic pole obtained by Pavlov et al. [1] for the southeastern margin of the Siberian platform, on the one hand, meets the requirements for paleomagnetic analysis. On the other hand, there are some doubt that this pole averages secular geomagnetic variations. Moreover, age of sills [1] needs verification and a possibility of tectonic rotation during the postcrystallization time has to be tested as well. In this study we discuss the dolerite sills exposed on the Sakhara and Allakh-Yun rivers with ages $974 \pm 7$ and $1005 \pm 4 \mathrm{Ma}$ [2], located $90-150 \mathrm{~km}$ north of Pavlov et al. sill's [1].

Paleomagnetic studies include both thermal (16 steps, to 640 ${ }^{\circ} \mathrm{C}$ ) and alternating field (20 steps, to $120 \mathrm{mT}$ ) demagnetization by using thermal demagnetizer MMTD-80, JR-6 magnetometer and cryogenic (SQUID) magnetometer $2 \mathrm{G}$ Enterprises. The paleomagnetic directions obtained are quite close to those already discussed [1].

Magnetic mineralogy experiments on vibration magnetometer (VSM) PMC MicroMag 3900, Vinogradov's thermomagnetometer and HITACHI TM 3000 SEM show that the main magnetic mineral in the studied samples is singledomain or pseudo-single-domain titanomagnetite and, more rare, hematite.

These data clarify and confirm the previously discussed paleomagnetic direction for the southeastern margin of the Siberian Platform [1], and also indicate that the region was not subjected to rotation. However, our estimation suggests that the existing pole should be attributed to the interval of 970-1000 Ma rather than $950 \mathrm{Ma}$.

The study is supported by Russian Scientific Foundation (grant No 19-77-10048).

[1] The Ui Group and Late Riphean Sills in the Uchur-Maya Area: Isotope and Paleomagnetic Data and the Problem of the Rodinia Supercontinent, Pavlov, V.E., Gallet, Y., Petrov, P.Y., Zhuravlev, D.Z., Shatsillo, A.V. (2002), Geotectonics 36, 278292.

[2] U-Pb geochronology of Riphean sandstone and gabbro from southeast Siberia and its bearing on the Laurentia-Siberia connection, Rainbird, R.H., Stern, R.A., Khudoley, A.K., Kropachev, A.P., Heaman, L.M., Sukhorukov, V.I. (1998), Earth Planet. Sci. Lett. 164, 409-420. 